\title{
EFFECT OF INDIVIDUAL AND COMBINED APPLICATION OF Trichoderma $s p$. AND VERMICOMPOST ON THE MANAGEMENT OF Sclerotium rolfsii AND GROWTH OF CHILLI UNDER PEATLANDS AGRO-CLIMATIC CONDITIONS
}

\author{
Adi Jaya,"\#, Bambang S. Lautt", Emmy Uthanya Antang, Lilies Supriati, Salampak Dohong \\ Faculty of Agriculture, University of Palangka Raya, J1. Yos Soedarso, Palangka Raya Indonesia \\ "Shared first author
}

Received - June 01, 2021; Revision - August 12, 2021; Accepted - August 25, 2021

Available Online-August 30, 2021

DOI: http://dx.doi.org/10.18006/2021.9(4).445.456

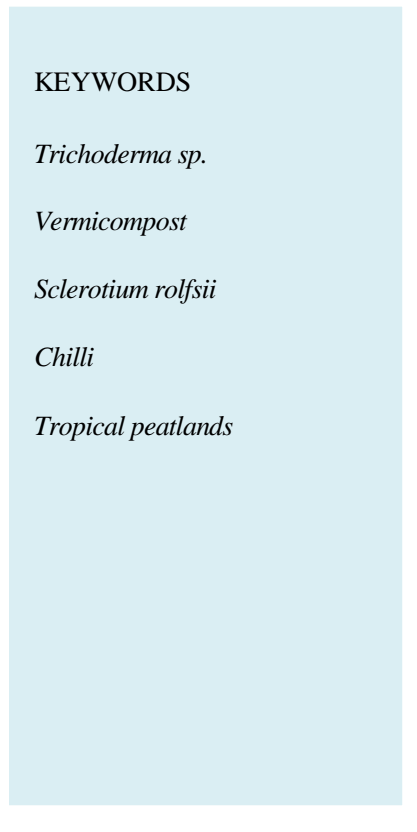

\begin{abstract}
This study was conducted to evaluate the biocontrol potential of Trichoderma sp., and vermicompost on the management of Sclerotium rolfsii and chilli plant growth under peatlands agro-climatic conditions. The research was conducted under the laboratory as well field condition of Palangka Raya University in a completely randomized factorial design. As a treatment, four doses of Trichoderma sp. i.e. 0, 5, 10, and $15 \mathrm{~g} / \mathrm{box}$, and three doses of Vermicompost i.e. 0,100 , and $200 \mathrm{~g} /$ box was used individually and in combination and each treatment have three replications. Three kilograms of sterilized peat soil planting media were placed in the 36 plastic boxes and Trichoderma sp., and vermicompost was applied 1 week before the chilli seeds are planted. After 10 weeks of plantations, observations related to the disease intensity and chilli growth and yield were recorded. The results of the study revealed a synergistic effect of Trichoderma sp. and vermicompost combination in controlling the stem rot disease caused by $S$. rolfsii. Individual and combined application of Trichoderma and vermicompost had an effective range of $73.33-100 \%$ over the control. Further, among the various tested treatments, a combination of Trichoderma sp@5g/box with vermicompost @ 200g/box and individual application of Trichoderma sp @ 10g/box were found superior in the management of stem rot disease. In the case of chilli growth parameters, the results of the study suggested that the application of vermicompost had a significant effect on the chilli plant's growth and yield, while the application of Trichoderma sp. significantly affects the chilli plants number of leaves.
\end{abstract}

* Corresponding author

E-mail: adijaya@agr.upr.ac.id (Adi Jaya)

Peer review under responsibility of Journal of Experimental Biology and Agricultural Sciences.

Production and Hosting by Horizon Publisher India [HPI] (http://www.horizonpublisherindia.in/).

All rights reserved.
All the articles published by Journal of Experimental Biology and Agricultural Sciences are licensed under a Creative Commons Attribution-NonCommercial 4.0 International License Based on a work at www.jebas.org.

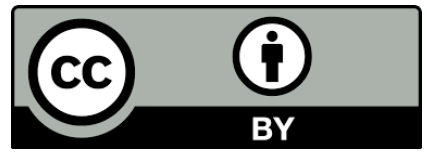




\section{Introduction}

The peatland area of Indonesia reached 13.43 million ha, it has a very high potential for agricultural extension but still, it is unexploited. For a long time, various efforts have been made to promote agricultural activities in this area but have not yet yielded maximum results (Anda et al., 2021). The low agricultural yield of peatlands is closely related to the various physical and chemical constraints, such as water dynamics, soil acidity, soil fertility including a low level of macro and micronutrients such as $\mathrm{N}, \mathrm{P}, \mathrm{K}$, $\mathrm{Ca}$, and $\mathrm{Mg}$ that could become limiting factors for plant growth and production (Alwi \& Hairani, 2007). Various efforts have been carried out to overcome these limitations; utilization of vermicompost resulting from agricultural waste could be an alternative to improve the quality of peat soil.

Chilli (Capsicum frutescens) is an important vegetable commodity with prospective business opportunities, containing high calories, protein, fat, carbohydrates, calcium, vitamins A, B1, and C (Piay et al., 2010). Pests and diseases are some of the most important obstacles in cultivating chili plants, especially if the disease attack occurs in the early vegetative phase, it can cause plant death. Chilli stem rot disease caused by $S$. rolfsii is one of the most important obstacles in chilli production in Indonesia. At an early stage, this fungal infection might cause up to $53.4 \%$ decreases in yield quality and quantity of chilli plants (Fery \& Dukes, 2005). S. rolfsii is an important pathogenic fungus that can cause several deadly plant diseases including stem rot, wilting, and sprouting collapse (Sukamto \& Dono, 2013). It is a long-lasting soil-borne fungus and survives in the form of sclerotia in soil, manure, and diseased plant debris. Due to the wide host range, facultative saprophytic nature, and formation of resting body like sclerotia, this pathogen can survive under environmental extremes and it is partly difficult to overcome under natural conditions, even fungicides are also not effective (Semangun, 1993; Sumartini, 2012). Further, excess use of chemical pesticides not only causing environmental pollution but also kill beneficial microorganisms. Biological control can be used as an alternative, various viruses, fungi, bacteria, or actinomycetes can be used as biological control agents against various plant pathogens (Tandon, 2008). The use of antagonistic microorganisms, resistant varieties, and mechanical means are some alternative methods that can be used for the management of S. rolfsii (Golafrouz et al., 2020). A combination of antagonistic microorganisms along with organic matter or fertilizers might be an alternative and have a significant effect on the management of S. rolfsii. Further, Supriati et al. (2007) reported that the combination of Trichoderma harzianum and cow manure can inhibited the $S$. rolfsii sclerotia formation. The use of biocontrol agents not only control the target organism but also increase the quantity and quality of agricultural products (Mukherjee et al., 2003; Tjut et al., 2011). The addition of organic matter in the form of cow dung manure to inland peat soils can enhance the role of the Trichoderma sp. Fungus, both as an antagonist for plant diseases and a decomposer can increase the carrying capacity of the soil as a growing medium, which will increase plant growth (Pandriyani et al., 2012).

Vermicomposting is a complex biological process that included many bacteria, fungi, and actinomycetes species that converts lowvalue materials into higher-value products. Various studies conducted on the application of vermicompost or vermiwash for plant protection have proven to be effective in suppressing pathogens and pests (Ersahin et al., 2009). Further, vermicompost is also a rich source of macro and micronutrients and contains various plant growth promoting hormones such as auxins, gibberellins, cytokinins, and beneficial microbes which not only increases the plant growth and yield but also increases the diversity and activity of antagonistic microorganisms, which helps in the suppression of various pests and diseases which caused plant diseases (Susanna et al., 2010; Komang et al., 2015; Yatoo et al., 2021). It is also reported that the application of vermicompost at the time to the nursery stage has a significant effect on the plant height, the number of leaves, and the width of leaves. In addition to this, the effect of vermicompost on seed development and seed growth was also reported (Pandriyani et al., 2012). The active ingredient of the compost can be absorbed by the roots and enter the plant tissue which enhances the plant growth and resistance. According to Oktarina (2007), vermicompost application can reduce the disease intensity of the dumping disease caused by Rizoctonia solani in tobacco nurseries by $92.50 \%$. The ability of vermicompost to suppress the intensity of pathogen attacks is also thought to be associated with the presence of toxic compounds in vermicompost that can inhibit pathogen development (Oktarina, 2007). Similarly, Oktarina et al. (2012) reported the presence of ammonia in the vermicompost during the decomposition process that can also suppress the development of pathogens.

There is not enough information available about the use of antagonistic microorganisms in combination with vermicompost for the management of chilli stem rot disease under peatland agricultural conditions, therefore, the current study was carried out to evaluate the effect of individual or combined application of antagonistic fungi Trichoderma sp., and vermicompost against soil-borne pathogens $S$. rolfsii.

\section{Materials and Methods}

This research was conducted at the Laboratory and Experimental Sites of the Department of Agronomy, Faculty of Agriculture, Palangka Raya University, Indonesia. The materials used in this study included the isolates of Trichoderma sp., S. rolfsii, cakra white chilli seeds, vermicompost, peat soil, rice, chopped corn, Potato Dextrose Agar (PDA) media, NPK fertilizer, and $70 \%$ 
alcohol. A plastic box measuring $30 \mathrm{~cm}$ long, $25 \mathrm{~cm}$ wide, and 10 $\mathrm{cm}$ high is used for planting chili.

The study used a factorial completely randomized design (CRD) consisting of two factors. Trichoderma sp. (T) had been considered as a primary factor with 4 levels i.e. $0,5,10$, and $15 \mathrm{~g} / \mathrm{box}$ (equal to $0,767,1,534$, and $2,300 \mathrm{~kg} \mathrm{ha}^{-1}$ ), while the vermicompost (V) had been considered as a secondary factor with 3 levels i.e. 0,100 , and $200 \mathrm{~g} / \mathrm{box}$ (equal to $0,15.3$, and 30.6 ton $\mathrm{ha}^{-1}$ ). Thus there were 36 experimental units from 12 treatments combination and three replications. Three kilograms/box of sterilized peat soil planting media were placed in 36 plastic boxes. Relevant dose of biocontrol agents Trichoderma sp., and vermicompost was inoculated in each pot 1 week before the chilli seeds planting. Observations related to the intensity of the disease, growth, and yield of chilli plants were taken until the plants were 10 weeks old.

\subsection{Seed nursery}

Chilli seeds were sown on the top of the soil in a nursery containing a mixture of peat soil and manure (2:1). The nursery was protected from the direct rain and sunlight. At the age of 4 WAS (weeks after sowing), these seedlings were transferred to a prepared plastic box having an already prepared mixture of peat soil planting media with a particular dose of Trichoderma sp., and vermicompost.

\subsection{Preparation of planting media}

The peat soil of the planting medium is sterilized, for this, first the collected peat soil is dry, followed by the hand crush of large sized clots and sieved with a size of $5 \mathrm{~mm}$ and sterilized by using a drum steamer with a minimum temperature of $100^{\circ} \mathrm{C}$ for 6 hours. From this, $3 \mathrm{~kg}$ of sterilized peat soil was filled into the selected plastic box having $30 \mathrm{~cm}$ long, $25 \mathrm{~cm}$ wide and $10 \mathrm{~cm}$ height measurement.

\subsection{Artificial infection of the pathogenic Sclerotium rolfsii}

Fungal pathogen $S$. rolfsii was multiplied on the PDA broth, and from this, $10 \mathrm{~g}$ of $S$. rolfsii inoculum was inoculated 10 days before planting of chilli seeds (3 days before Trichoderma sp. application) in each pot containing planting medium. S. rolfsii was inoculated at the depth of $3 \mathrm{~cm}$ from the surface of the planting medium and this was followed by covering a thin layer of soil (Susanna et al., 2010).

\subsection{Application of Trichoderma sp., vermicompost and dolomite}

Isolated Trichoderma sp. has been multiplied on the rice grain substrate as per the predecided treatment i.e. $0 \mathrm{~g} / \mathrm{box}\left(\mathrm{T}_{0}\right), 5 \mathrm{~g} / \mathrm{box}$ $\left(\mathrm{T}_{5}\right), 10 \mathrm{~g} / \mathrm{box}\left(\mathrm{T}_{10}\right)$, and $15 \mathrm{~g} / \mathrm{box}\left(\mathrm{T}_{15}\right)$. While three doses of the vermicompost i.e. $0 \mathrm{~g} / \mathrm{box}\left(\mathrm{V}_{0}\right), 100 \mathrm{~g} / \mathrm{box}\left(\mathrm{V}_{100}\right)$, and $200 \mathrm{~g} / \mathrm{box}$
$\left(\mathrm{V}_{200}\right)$ were used as a treatment (Susanna, 2010). Individual as well as combined application of Trichoderma sp., and vermicompost was carried out 7 days before planting of chilli in the potting soil containing $S$. rolfsii and it was followed by the covering it with soil. Further, Dolomite @ 26.19g/box was applied 7 days before planting, while application of NPK fertilizer @ 0.48g/box was carried out two weeks after planting.

\subsection{Transplanting of chilli seedlings}

Four weeks after chilli seeds sowing, three leaves stage healthy chilli seeding having similar height were transplanted to planting medium containing plastic boxes. Each plastic box was planted with 10 chili seedlings with a spacing of $7 \mathrm{~cm}$ between each seedling.

\subsection{Observation and Data collection}

Various parameters related to disease control, plant growth, and production has been recorded after the study. In growth parameters, plant height and number of leaves were measured at 1 to 10 WAP (weeks after planting), while flowering age and yield were measured in the case of production parameters. Flowering age was observed after the plant formed flowers (bloom), while fruit weight was measured by weighing the harvested yellow to reddish color fruit. Disease intensity was observed 1 to 4 weeks after planting. The intensity of stem rot disease was calculated using the formula given by Sukamto (2003):

$$
I=\frac{a}{a+b} \times 100 \%
$$

where:

$\mathrm{I}=$ Intensity of disease attack (\%);

$a=$ number of dead plants;

$\mathrm{b}=$ number of living plants

Similarly, the control effectiveness was also calculated by using the formula given by Sukamto (2003):

$$
\mathrm{Ea}=\frac{\mathrm{IPk}-\mathrm{IPp}}{\mathrm{IPk}} \times 100 \%
$$

where:

$\mathrm{Ea}=$ Antagonist effectiveness;

$\mathrm{IPk}=$ Disease intensity in controls (no treatment);

$\mathrm{IPp}=$ Disease intensity with treatment

While the effectiveness values are categorized as very good $(\mathrm{Ea}>$ $69 \%)$, good $(\mathrm{Ea}=50-69 \%)$, less good $(\mathrm{Ea}=30-49 \%)$ and not $\operatorname{good}(\mathrm{Ea}=<30 \%)$ as suggested by Sukamto, (2003). 


\subsection{Data Analysis}

Data related to disease intensity, number of sclerotium (propagules), plant height, and number of leaves/plant were analyzed using analysis of variance ( $F$ test) at the levels of $p=5 \%$ and $\mathrm{p}=1 \%$. If the analysis of variance results showed the significant effect of the treatment, it was followed by the Honestly Significant Difference test (HSD) at the level of $\mathrm{p}=5 \%$.

\section{Results and Discussion}

\subsection{Disease Intensity}

Based on the analysis of variance results, it revealed that at the age of 1 week after planting (WAP), individual or combined application of Trichoderma sp., and vermicompost did not have any significant effect against the intensity of seedling felling disease in chili plants. While at the stage of 2, 3, and 4 WAP, an interaction effect of Trichoderma sp., and vermicompost was reported on the disease intensity. The mean disease intensity of seedling feeling chilli by the $S$. rolfsii pathogen is presented in table 1 .

The attack of S. rolfsii on chilli seedlings began from the 1 to 4 WAP. On the first week of planting, the intensity of the $S$. rolfsii attack was reported only in the control treatment $\left(\mathrm{T}_{0} \mathrm{~V}_{0}\right)$. Afterward disease intensity increased with the increasing time duration and it was reported highest in the control treatment which was significantly different from other treatments $\left(\mathrm{T}_{0} \mathrm{~V}_{0}\right)$. After four weeks of planting, the least disease intensity was recorded in the various combinations of the Trichoderma sp., and vermicompost. While no intensity of $S$. rolfsii infection was not recorded in the treatment $\mathrm{T}_{10} \mathrm{~V}_{0}$ and $\mathrm{T}_{5} \mathrm{~V}_{200}$, and this might be because of the suppressive effect of the Trichoderma fungi against the $S$. rolfsii. In general, the antagonism mechanism of Trichoderma sp. is known as mycoparasitic and aggressive competitors (Baker \& Cook, 1982). Initially, the hyphae of Trichoderma sp. grows lengthwise, twisted around the pathogenic fungi, and penetrated in the pathogenic fungi with the help of a hook-like structure called the haustorium, after penetration it create vacuolation, lysis inside the pathogenic microorganisms and finally disintegrates the pathogens (Tjut et al., 2011). According to Harjono \&Widyastuti (2001) and Chatterton \& Punja (2009), hyphae of Trichoderma penetrated the host cell with the help of cell wall degrading enzymes chitinase, $\beta-1,3$ glucanase, and protease and use the contents of the pathogenic fungi as a food source. Some time it damaged the cell wall of the pathogenic fungi and because of this the cellular contents of the pathogenic fungi came out and became the cause of death. Along with cell wall degrading enzymes, Trichoderma sp. also produce some antibiotics such as glyotoxin and viridian which reduced the multiplication of pathogenic microorganisms (Harman, 2006; Zin \& Badaluddin, 2020).
Simultaneously Trichoderma sp. also released some anti-fungal compounds of the peptaibol class and furanon compounds which inhibited the growth of pathogenic fungal spores and hyphae (Ordentlich et al., 1992; Ahluwalia et al., 2015; El-Katatny \& Emam, 2021). The vermicompost is an organic material can provide a food supply to the biological control agents and plant root in the soil. The high intensity of disease attacks in the treatment $T_{0} V_{100}$ and $T_{15} V_{100}$ was thought to be due to competition between other microbes such as bacteria found in the growing media. The number of antagonist agents Trichoderma sp. $0.67 \mathrm{x}$ $10^{4}$ cfu in the $\mathrm{T}_{0} \mathrm{~V}_{100}$ and $\mathrm{T}_{15} \mathrm{~V}_{100}$ treatments was less than the number of other bacteria $\left(17.67 \times 10^{4} \mathrm{cfu}\right)$, and because of this Trichoderma sp. possibly fighting with other microorganisms for a place to grow or food sources and this might reduce the antagonist behavior of Trichoderma sp. (Jaya et al., 2020a).

\subsection{Effectiveness of Control}

Trichoderma sp. and vermicompost, both singly or in combination were able to control the multiplication of S. rolfsii and can be used as an effective disease management strategy against the seedling felling disease of Chilli. This ability can be measured by calculating the effectiveness value as suggested by Sukamto (2003), and the results of Trichoderma sp., and vermicompost effectiveness against the seedling falling disease of chilli at the age of 4 WAP are presented in figure 1.

Control effectiveness of the Trichoderma with vermicompost combination was reported between 73.33 - 100\%, which is categorized as very good as per the criteria given by Sukamto (2003). The highest control effectiveness was found in the treatment having $T_{10} V_{0}$ and $T_{5} V_{200}$ with an effectiveness value of $100 \%$. The suppression reported in treatment $\mathrm{T}_{10} \mathrm{~V}_{0}$ might be due to the mycoparasites properties of the Trichoderma sp which will suppress the population of the pathogenic fungi. The existence of antagonistic microorganisms in the soil is desirable for a long period; therefore it is necessary to supply foodstuffs capable of maintaining the survival of these biological agents. Organic matter applied to the soil is not only a source of nutrition for these antagonistic microorganisms but also helps in increasing their activity, stimulate the dormancy of pathogenic propagules, and exaggerated the fungistatic effect on soil-borne pathogens (Sunarti et al., 2015). The ability of vermicompost to increase the activity of soil microorganisms is not only during the application of vermicompost but can last a long time. It is found that microorganisms can grow continuously for almost one year after being given vermicompost treatment (Mulat, 2003). Similarly, Ersahin et al. (2009) found that vermicomposts without $T$. harzianum effectively controlled the damping-off disease of cucumber caused by $R$. solani at the rate of $20 \%$ and $30 \%$, while vermicompost with and without $T$. harzianum can improve plant growth. 
Table 1 Average Attack Intensity (\%) of Sclerotium rolfsii Pathogen on Chilli on Vermicompost and Trichoderma sp.

\begin{tabular}{|c|c|c|c|c|}
\hline \multirow{2}{*}{ Observation } & \multirow{2}{*}{ Trichoderma $(\mathrm{T})$} & \multicolumn{3}{|c|}{ Vermicompost (V) } \\
\hline & & $\mathrm{V}_{0}$ & $\mathrm{~V}_{100}$ & $\mathrm{~V}_{200}$ \\
\hline \multirow{4}{*}{$1 \mathrm{WAP}$} & $\mathrm{T}_{0}$ & 10.00 & 0.00 & 0.00 \\
\hline & $\mathrm{T}_{5}$ & 0.00 & 0.00 & 0.00 \\
\hline & $\mathrm{T}_{10}$ & 0.00 & 0.00 & 0.00 \\
\hline & $\mathrm{T}_{15}$ & 0.00 & 0.00 & 0.00 \\
\hline & HSD $5 \%$ & 0.00 & & \\
\hline \multirow{4}{*}{$2 \mathrm{WAP}$} & $\mathrm{T}_{0}$ & $20.00^{\mathrm{b}}$ & $3.33^{\mathrm{a}}$ & $0.00^{\mathrm{a}}$ \\
\hline & $\mathrm{T}_{5}$ & $0.00^{\mathrm{a}}$ & $0.00^{\mathrm{a}}$ & $0.00^{\mathrm{a}}$ \\
\hline & $\mathrm{T}_{10}$ & $0.00^{\mathrm{a}}$ & $0.00^{\mathrm{a}}$ & $0.00^{\mathrm{a}}$ \\
\hline & $\mathrm{T}_{15}$ & $3.33^{\mathrm{a}}$ & $6.67^{\mathrm{a}}$ & $6.67^{\mathrm{a}}$ \\
\hline & HSD $5 \%$ & & 5.44 & \\
\hline \multirow{4}{*}{$3 \mathrm{WAP}$} & $\mathrm{T}_{0}$ & $36.67^{\mathrm{d}}$ & $13.33^{\mathrm{c}}$ & $3.33^{\mathrm{ab}}$ \\
\hline & $\mathrm{T}_{5}$ & $6.67^{\mathrm{abc}}$ & $3.33^{\mathrm{ab}}$ & $0.00^{\mathrm{a}}$ \\
\hline & $\mathrm{T}_{10}$ & $0.00^{\mathrm{a}}$ & $3.33^{\mathrm{ab}}$ & $6.67^{\mathrm{abc}}$ \\
\hline & $\mathrm{T}_{15}$ & $3.33^{\mathrm{ab}}$ & $10.00^{\mathrm{bc}}$ & $6.67^{\mathrm{abc}}$ \\
\hline & HSD $5 \%$ & & 7.68 & \\
\hline \multirow{4}{*}{4 WAP } & $\mathrm{T}_{0}$ & $50.00^{\mathrm{d}}$ & $13.33^{\mathrm{c}}$ & $3.33^{\mathrm{ab}}$ \\
\hline & $\mathrm{T}_{5}$ & $6.67^{\mathrm{abc}}$ & $6.67^{\mathrm{abc}}$ & $0.00^{\mathrm{a}}$ \\
\hline & $\mathrm{T}_{10}$ & $0.00^{\mathrm{a}}$ & $3.33^{\mathrm{ab}}$ & $6.67^{\mathrm{abc}}$ \\
\hline & $\mathrm{T}_{15}$ & $3.33^{\mathrm{ab}}$ & $10.00^{\mathrm{bc}}$ & $6.67^{\mathrm{abc}}$ \\
\hline & HSD $5 \%$ & & 7.66 & \\
\hline
\end{tabular}

Figures followed by the same letter at the same time observation are not significantly different based on the 5\% Honestly Significant Difference (HSD) test; $\mathrm{T}_{0}=$ Without Trichoderma $\mathrm{sp} ; \mathrm{T}_{5}=$ Trichoderma $\mathrm{sp} @ 5 \mathrm{~g} / \mathrm{box}, \mathrm{T}_{10}=$ Trichoderma $\mathrm{sp} @ 10 \mathrm{~g} / \mathrm{box} ; \mathrm{T}_{15}=$ Trichoderma sp @ $15 \mathrm{~g} / \mathrm{box} ; \mathrm{V}_{0}=$ Without Vermicompost; $\mathrm{V}_{100}=$ Vermicompost @ $100 \mathrm{~g} / \mathrm{box} \mathrm{V}_{200}=$ Vermicompost @ 200 g/box

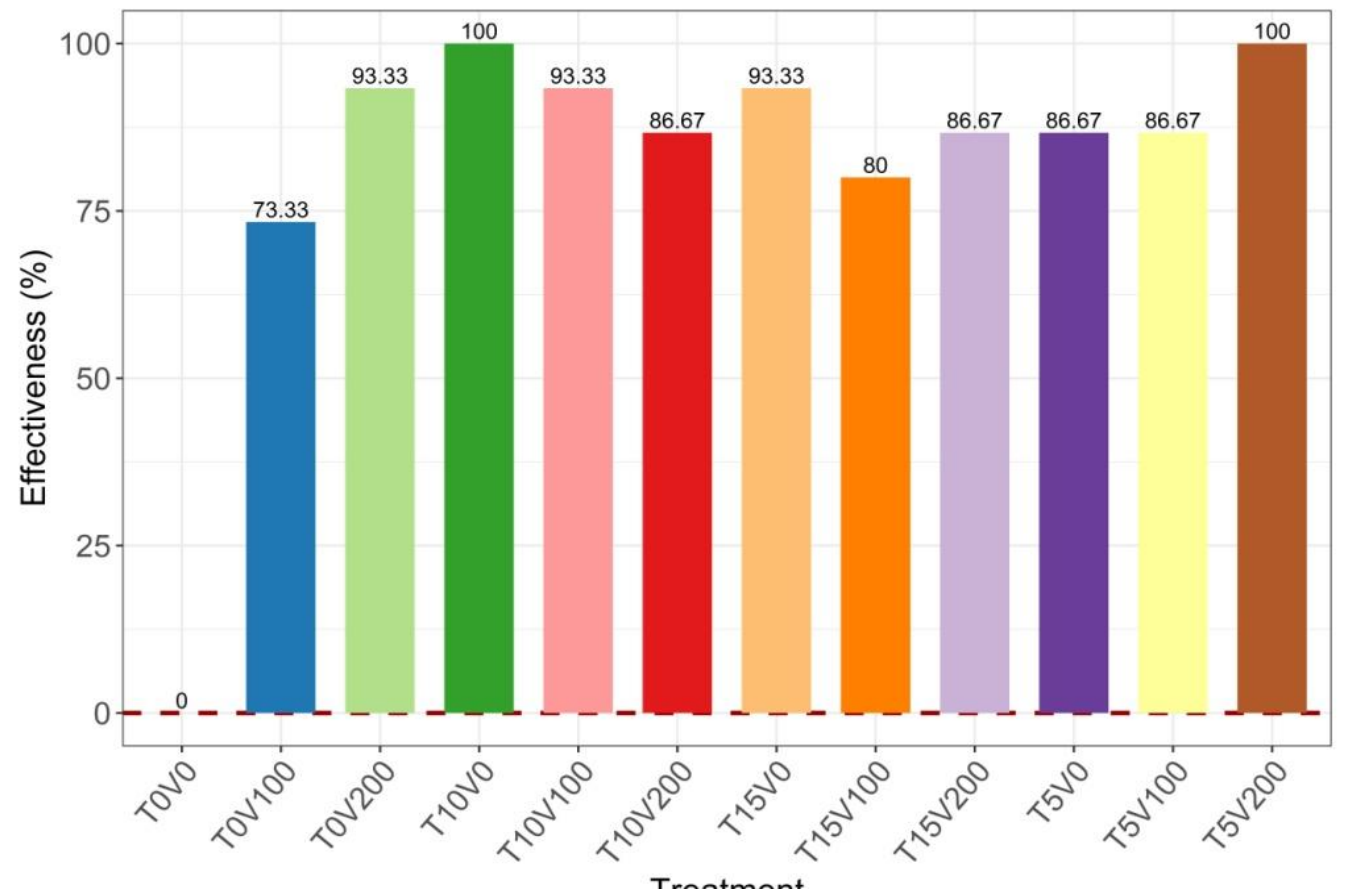

Treatment

Figure 1 The effectiveness of Trichoderma sp. and Vermicompost in suppressing seedling of Chilli plants in 4 WAP

(Here $\mathrm{T}_{0}=$ Without Trichoderma $\mathrm{sp} ; \mathrm{T}_{5}=$ Trichoderma $\mathrm{sp} @ 5 \mathrm{~g} / \mathrm{box}, \mathrm{T}_{10}=$ Trichoderma $\mathrm{sp} @ 10 \mathrm{~g} / \mathrm{box} ; \mathrm{T}_{15}=$ Trichoderma sp @ $15 \mathrm{~g} / \mathrm{box}$;

$\mathrm{V}_{0}=$ Without Vermicompost; $\mathrm{V}_{100}=$ Vermicompost @ $100 \mathrm{~g} / \mathrm{box} \mathrm{V}_{200}=$ Vermicompost @ $\left.200 \mathrm{~g} / \mathrm{box}\right)$

Journal of Experimental Biology and Agricultural Sciences http://www.jebas.org 
a)

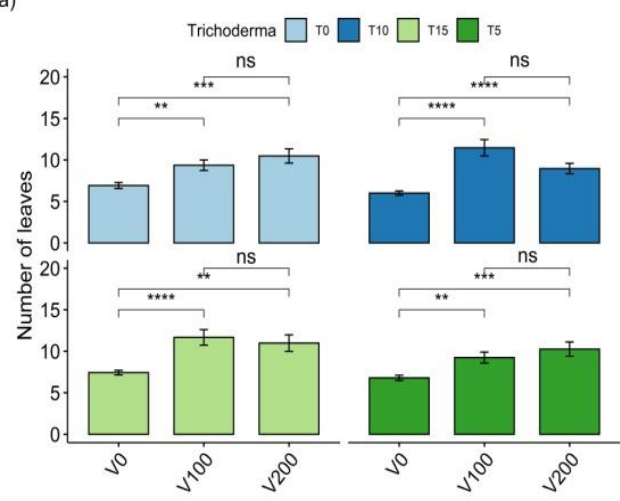

c)

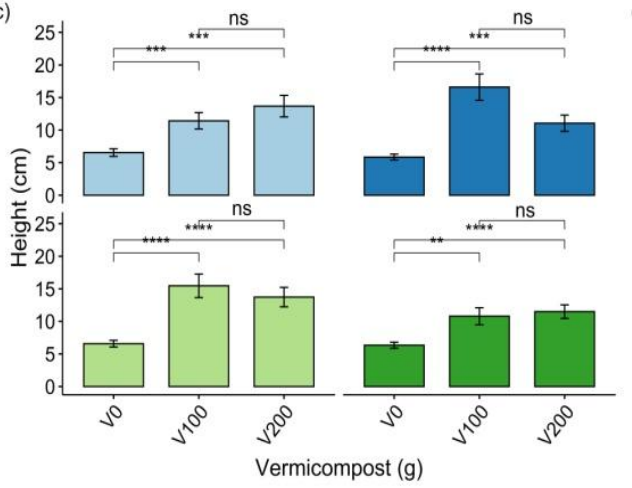

b)

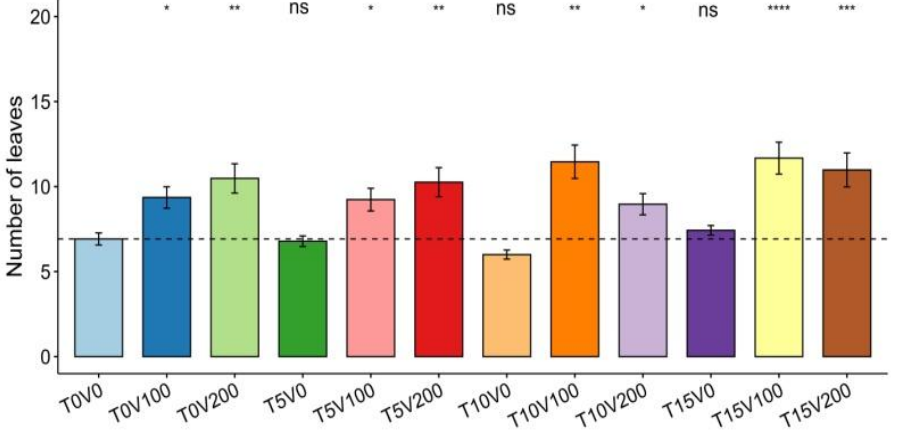

d)

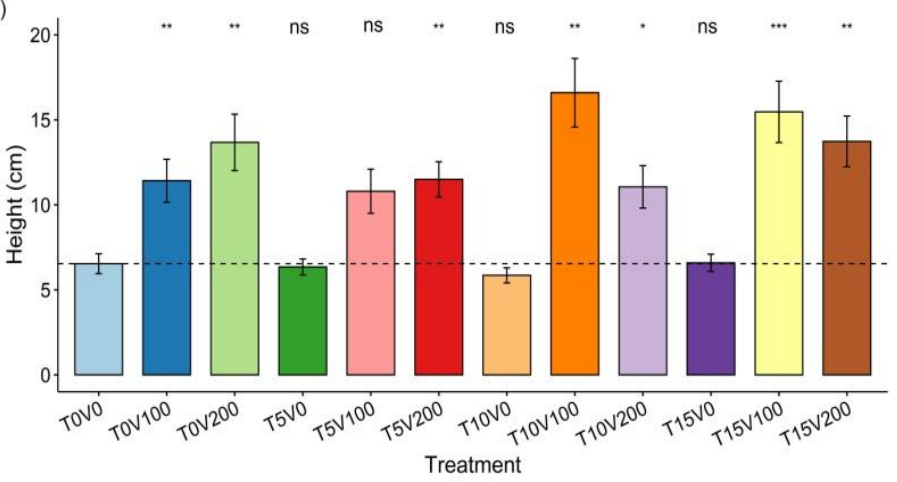

Figure 2 Plant height and leaf number due to vermicompost application at several dose of Trichoderma sp. (a and b); Combination of Trichoderma sp. and vermicompost (c and d); Descriptions of treatments are similar to figure 1.

\subsection{Plant Height and Number of Leaves}

The results related to the effects of vermicompost and Trichoderma spp., on plant height and the number of leaves are presented in figures 2, 3, 4, and 5. Figure 2 demonstrates that application vermicompost significantly increased the plant height and number of leaves at all levels of Trichoderma sp. Application of vermicompost at the level $\mathrm{V}_{100}$ increased plant height growth significantly as compared to the control (without vermicompost). While the higher dose of vermicompost $\left(\mathrm{V}_{200}\right)$ did not tend to show any significant difference as compared to the $\mathrm{V}_{100}$ dose Vermicompost is an organic fertilizer that uses organic materials such as agricultural or livestock waste through a composting process carried out by worms. Vermicompost plays an important role in increasing soil fertility by improving the ability to hold water, helping to provide nutrients for plants, and improving soil structure (Nofianti, 1999; Hardiyanti et al., 2014). Vermicompost has fairly higher organic matters including $24-30 \%$ organic C, 2$2.5 \%$ total $\mathrm{N}, 1,300-1,800$ ppm $\mathrm{P}_{2} \mathrm{O}_{5}$, and bases such as $\mathrm{Ca}, \mathrm{Mg}, \mathrm{K}$, and $\mathrm{Na}$, which is good for plant growth (Jaya et al., 2020b).

On the other hand, the application of Trichoderma sp. to chilies did not show any significant effect on plant height and leaf number at all levels of vermicompost (Figure 3). Further, Trichoderma is a fungus that functions as an organic pesticide as well as fertilizer. Trichoderma parasitized various other types of fungi including Fusarium oxsporum, Ralstonia solanacearum, Rizoctonia solani, Phytopthora infestans, and others, which are known to cause root rot, stem rot disease to the chili plants. Further, it also inhibits the growth and spread of other soil born pathogens. As a biofertilizer, Trichoderma improves the soil structure around plant roots by breaking down organic substances in the soil.

The growth pattern of chili plants in the early stages of growth from the first week to the fourth week tends to be the same because at that time the plants were still in a slow vegetative growth phase (Figure 4). From the fifth to the tenth week, plant growth increased rapidly as the plant entered in the active vegetative phase. Plant vegetative growth was strongly influenced by the application of vermicompost, especially for the plant height and the number of leaves. Among the various tests combinations, treatment $T_{10} V_{100}$ shows superiority over the rest treatment in the case of vegetative growth. Another interesting thing is that treatment $\mathrm{V}_{200}$ increased both plant height and the number of leaves even in the absence of Trichoderma. Vermicompost treatment gives a good response to high growth and the number of leaves to chilli plants. 
a)

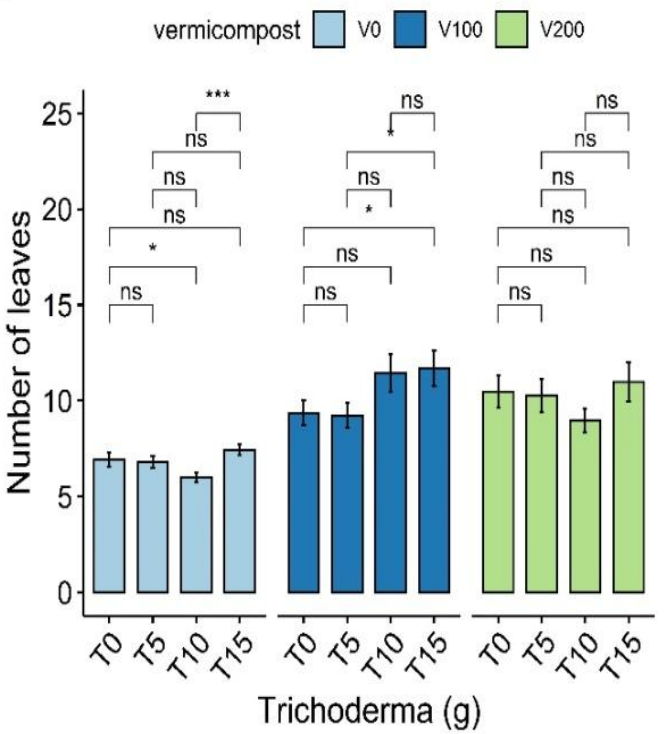

b)

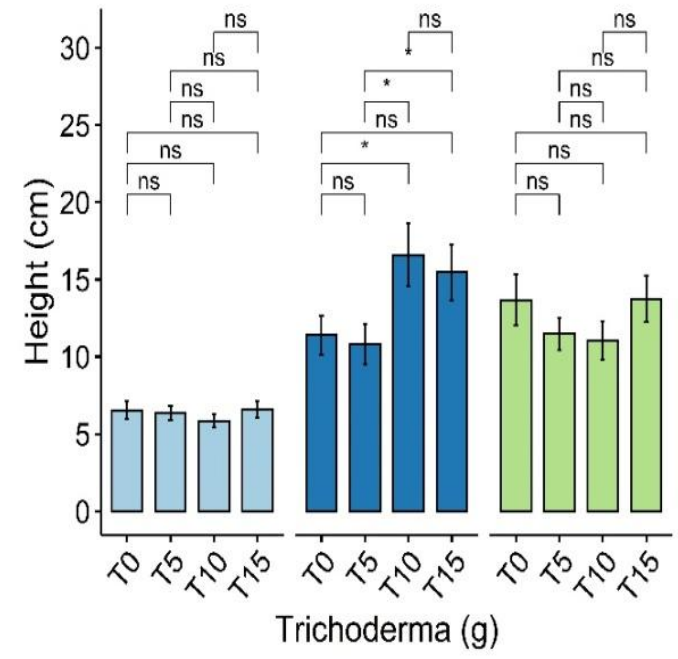

Figure 3 Number of leaves and plant height on Trichoderma sp. application and several doses of vermicompost; Descriptions of treatments are similar to figure 1.

a)

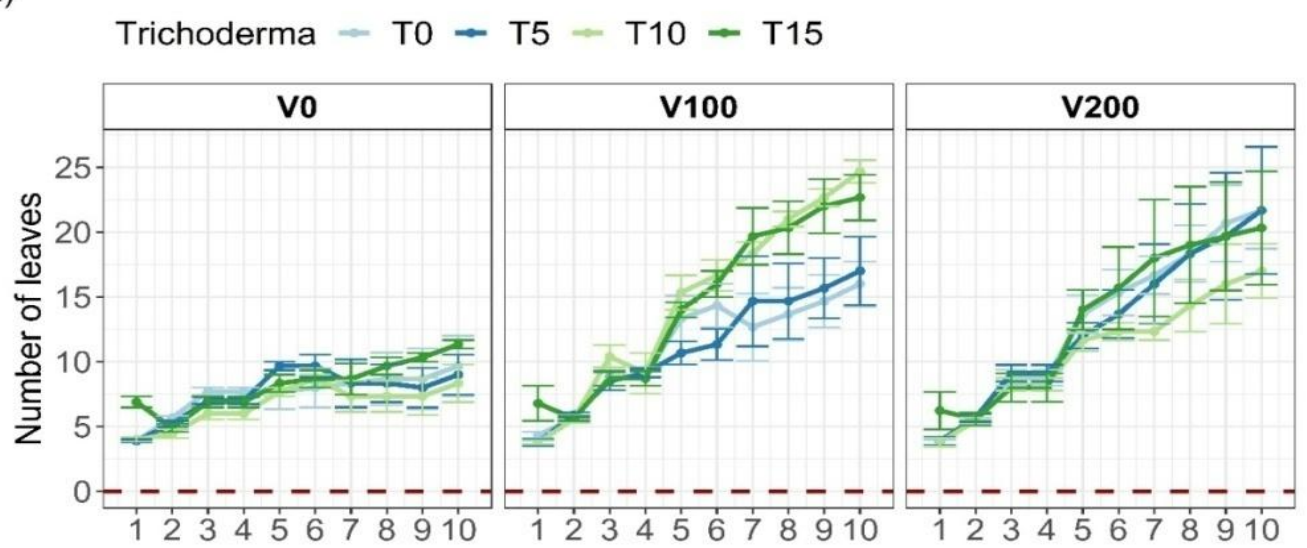

b)

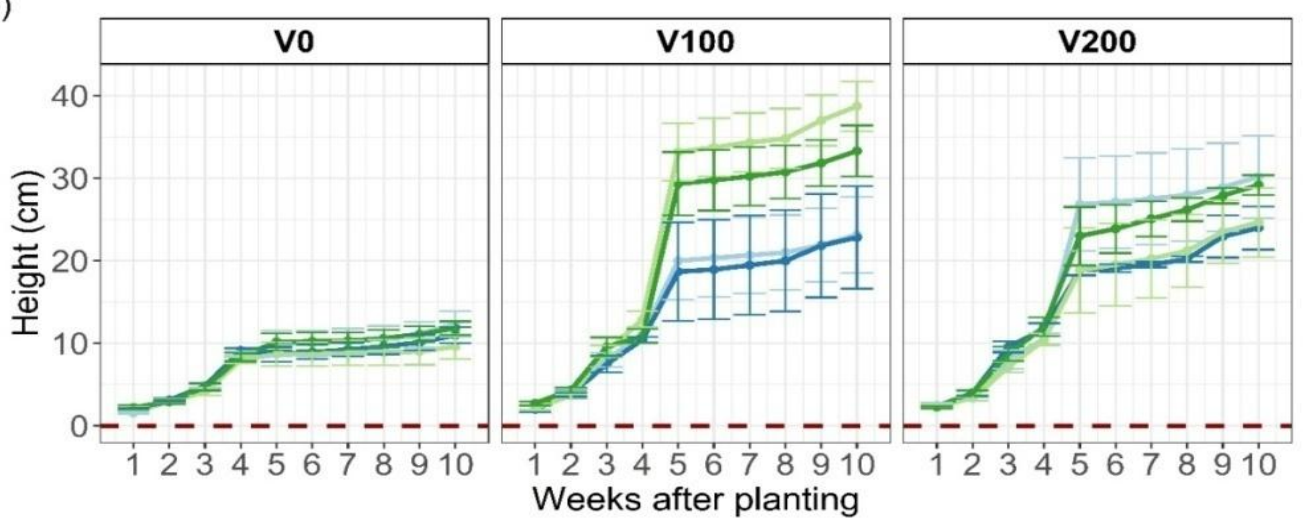

Figure 4 Height and number of leaves on Trichoderma sp application at various levels of Vermicompost; Descriptions of treatments are similar to figure 1. 
Results represented in figure 5 revealed that the treatment $T_{0}$ and $\mathrm{T}_{5}$ have a significant effect on the number of leaves and plant height. While Trichoderma sp. at the level of $\mathrm{T}_{10}$ and $\mathrm{T}_{15}$ with vermicompost at $\mathrm{V}_{100}$ level significantly increased plant height and leaf number. This shows that these two agents have a synergistic effect on the plant height and leaf number. Similar higher plant growth was obtained by Rahmadhaini et al. (2017) when they applied vermicompost fertilizer in soybean plants.

The vermicomposts are superior organic fertilizers because they not only contain various macro and micronutrients but also have growth hormones that are readily absorbed by the plants. The increase in plant height is closely related to nitrogen, phosphorus, and potassium. Nitrogen is the main ingredient for amino acids, proteins, and the formation of cell protoplasm which can stimulate plant growth (Manahan et al., 2016). The important function of phosphorus in plants is in the photosynthetic process, energy transfer and storage, cell division, enlargement, and processes in plants that can stimulate root growth, affecting the above-ground part's growth (Winarso, 2005). Previous researches also suggested that potassium acts as an activator of various essential enzymes in photosynthesis, respiration and starch, and protein synthesis (Lakitan, 1996). The resulting photosynthate is used by plants for plant cell division which improved plant growth.

According to Rahmawati (2021), the higher dosage and frequency of vermicompost applications will play a significant role in increasing plant growth because it contains various macronutrients such as carbon $(\mathrm{C})$, nitrogen $(\mathrm{N})$, phosphorus $(\mathrm{P})$, potassium $(\mathrm{K})$, and other micronutrient elements. The presence of other micronutrients such as zinc $(\mathrm{Zn})$, copper $(\mathrm{Cu})$, manganese $(\mathrm{Mn})$ in the vermicompost also helps in fertilizing plants and inducing systemic plant resistance. In addition, vermicompost can also improve the physical properties of the soil by making the soil loose, increasing soil porosity and water holding capacity, which help the plant's roots to go dipper and absorb more nutrients so that plants can become healthier more disease resistant. Besides, vermicompost can also improve the biological properties of the soil; thus beneficial microbes such as Trichoderma sp. in the soil will develop well and will affect the development of pathogens through antagonistic mechanisms.
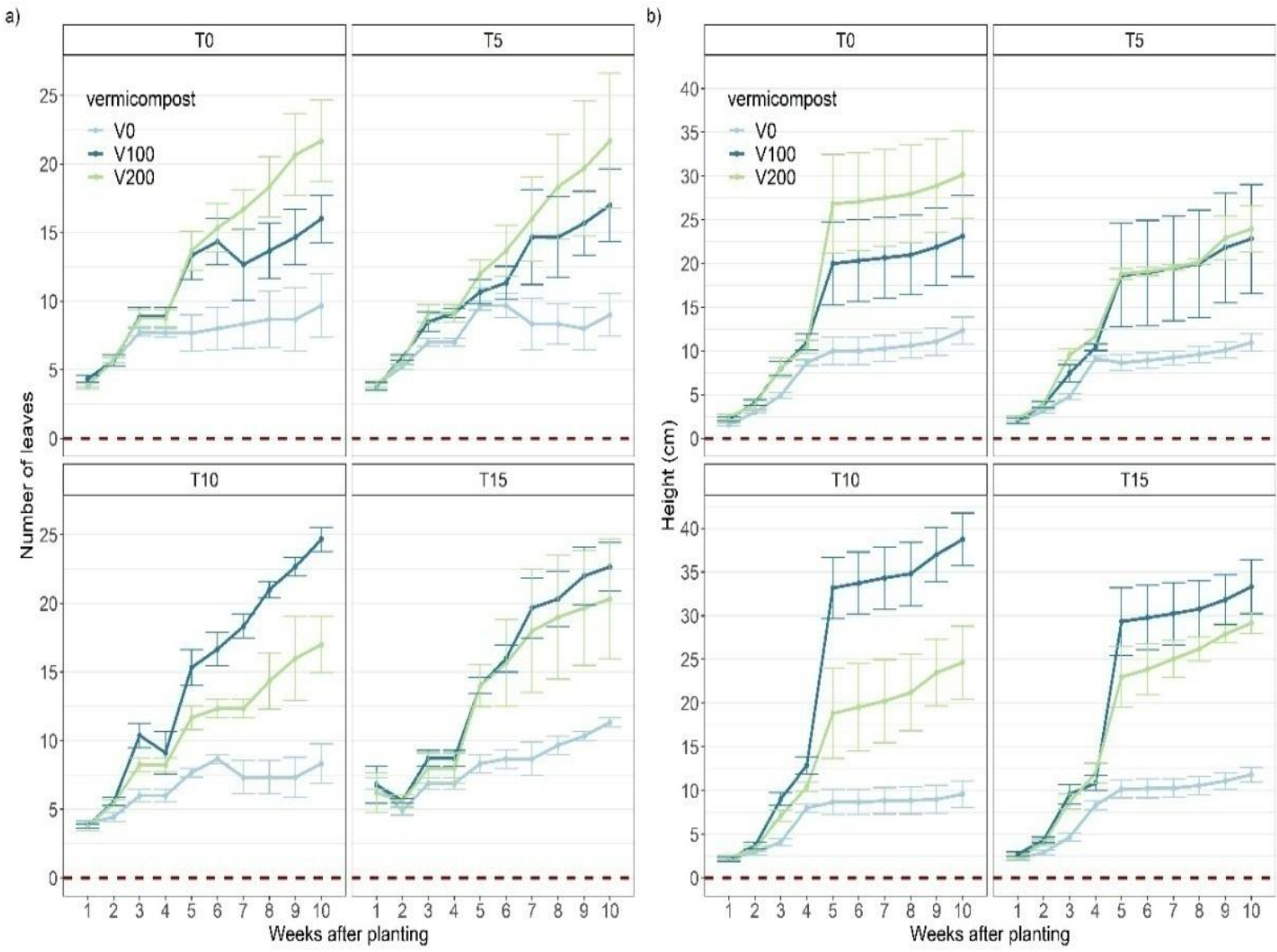

Figure 5 Plant heights and numbers of leaves due to application of various levels of Trichoderma sp., Descriptions of treatments are similar to figure 1. 


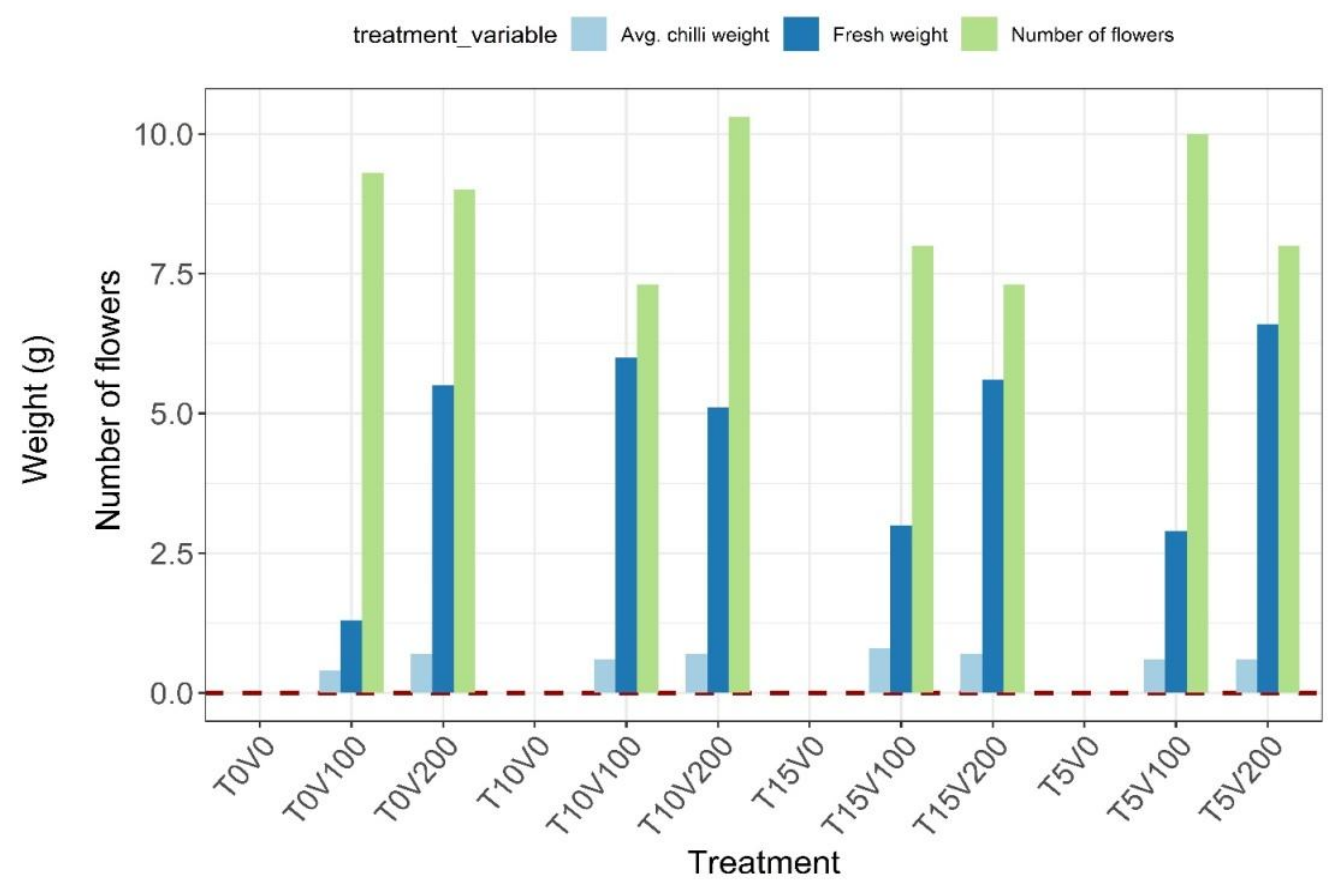

Figure 6 Number of Flowers, Weight of Fresh Fruits, and Average Weight per Fruit; Descriptions of treatments are similar to figure 1.

The results of the analysis of various combinations of Trichoderma sp. and vermicompost showed a non-synergistic effect of this combination on the number of leaves of chili plants for the first four weeks (Figures 4 and 5). Based on the average number of leaves and height of chili plants data, the impact of the treatment with Trichoderma and vermicompost only appears when the plants were 5 WAP. Nutrients requirement of the chilli plants, especially for nitrogen elements, was recorded higher when the plants are 4 or $5 \mathrm{WAP}$ and these nitrogen elements can stimulate the overall plant growth including the number of leaves (Rahmadhaini et al., 2017). According to Cartika et al. (2016), a significant difference in the number of curly red chili leaves at the age of $8 \mathrm{WAP}$ is probably related to the doses of Trichoderma sp and these researchers reported that $200 \mathrm{ml}$ dose of Tricho-G provides the greatest number of leaves, which is likely the optimal dose. While the 300 $\mathrm{ml}$ dose of Tricho-G reduced the number of leaves and the results were the same as without Tricho-G treatment. This is presumably due to the higher dosage of Trichoderma sp. around the plant roots which might be induced the competition between the plant and the fungus for nutrient uptake (Singh et al., 2014).

\subsection{Number of Flowers, Weight of Fresh Fruits}

Figure 6 demonstrates the effect of Trichoderma and vermicompost application on the number of flowers and weight of fresh fruit of chili. The Trichoderma sp., and vermicompost showed a significant effect on the generative components of plants. In the absence of vermicompost application, Trichoderma sp. did not show any effect on all generative components of chilli plants which suggested that vermicompost plays an important role in the production of flowers and fruit. In addition, the number of fruit set and fresh weight of chilli fruit also increases with the increasing dose of vermicompost. As is well known, leaves function as photosynthetic organs for plants, and under good growth conditions, the resulting photosynthate can be used for the development of reproductive organs such as flowers and fruit. Vermicompost as an organic fertilizer provides suitable nutrients to plants which result in higher plant growth, fruit development, and fruit weight. Joshi et al. (2015) stated that vermicompost could significantly improve the soil's physical and chemical properties, and increase soil nutrients, organic matter, and enzymatic activities (Firmansyah et al., 2019; Wirawan et al., 2021; Bayram et al., 2021). Further, Jaya et al. (2020a) suggested that the application of vermicompost improves the chemical properties of the peat soil.

\section{Conclusions}

Based on the research results, it can be concluded that the interaction between the Trichoderma sp., and vermicompost have a significant effect on the controlling seedling disease caused by the fungus $S$. rolfsii. Among the tested doses, the combination treatment having $T_{5} V_{200}$ and $T_{10} V_{0}$ was reported best in managing this disease. Control effectiveness was categorized as very good with a control effectiveness value range of 73.33 - 100\%. Further, the application of vermicompost also has a significant effect on the 
vegetative and reproductive growth of the chilli, but a nonsignificant interaction effect was reported in the combination of Trichoderma sp., and vermicompost and the single-dose treatments of Trichoderma sp.

\section{Acknowledgment}

The authors expressed their gratitude to the Institute of Research and Community Services (LPPM) of Palangka Raya University for financial support as well as encouraged and provided UPR staff opportunities to conduct research. Also to Dr. Jovani Jonay Sancho of University of Nottingham, UK, who help in statistical analysis.

\section{Conflict of Interest}

The authors would hereby like to declare that all authors have no conflict of interest. The funding sponsors had no role in the study's design, in the collection, analyses, or interpretation of data, in the writing of the manuscript, and in the decision to publish the results.

\section{References}

Ahluwalia V, Kumar J, Rana VS, Sati OP, Walia S (2015) Comparative evaluation of two Trichoderma harzianum strains for major secondary metabolite production and antifungal activity. Natural Product Research 29:914-920. https://doi.org/10.1080/ 14786419.2014.958739.

Alwi M, Hairani A (2007) Karakteristik kimia lahan gambut dangkal dan potensinya untuk pertanaman cabai dan tomat. Jurnal Agronomi Indonesia 35 (1): 36-43.

Anda M, Ritung S, Suryani E, Sukarman, Hikmat M, Yatno E, Mulyani A, Subandiono RE, Suratman, Husnain (2021) Revisiting tropical peatlands in Indonesia: Semi-detailed mapping, extent and depth distribution assessment. Geoderma 402: 115235. DOI: https://doi.org/10.1016/j.geoderma.2021.115235.

Baker KF, Cook RJ (1982) Biological Control of Plant Pathogens. The American Phytopathology Society. Minnessota Fravel. Reprinted edition, Pp. 433.

Bayram CA, Büyük G, Kaya A (2021) Effects of Farm Manure, Vermicompost and Plant Growth Regulators on Yield and Fruit Quality in Watermelon. KSU Journal of Agriculture and Nature 24 (1): 64-69. https://doi.org/10.18016/ksutarimdoga.vi.701708.

Cartika I, Dani U, Asminah (2016) Pengaruh Cendawan Trichoderma sp. dan Pupuk Nitrogen Terhadap Pertumbuhan dan Produksi Cabai Merah Keriting (Capsicum annuum L.). Journal of Agriculture Sciences and Veteriner 4 (1): 47-54.
Chatterton S, Punja Z (2009) Chitinase and $\beta$-1,3-glucanase enzyme production by the mycoparasite Clonostachys rosea $\mathrm{f}$. catenulata against fungal plant pathogens. Canadian Journal of Microbiology 55(4):356-67. https://doi.org/10.1139/w08-156.

El-Katatny MH, Emam AS (2021) Control of postharvest tomato rot by spore suspension and antifungal metabolites of Trichoderma harzianum. Journal of Microbiology, Biotechnology and Food Sciences 1 (6) :1505-1528.

Ersahin YS, Haktanir K, Yanar Y (2009) Vermicompost suppresses Rhizoctonia solani Kühn in cucumber seedlings. Journal of Plant Diseases and Protection 116 (4): 182-188. https://doi.org/10.1007/BF03356308.

Fery RL, Dukes PD (2005) Potential for utilization of pepper germplasm with a variable reaction to Sclerotium rolfsii Sacc. to develop southern blight-resistant pepper (Capsicum annuит L.) cultivars. Plant Genetic Resources 3 (3): 326-330. https://org.doi/ 10.1079/PGR200586.

Firmansyah I, Iriani F, Widyastuti SN (2019) Pertumbuhan dan Hasil Tanaman Kangkung Darat pada Media Tanam Kascing dengan Takaran yang Berbeda. Jurnal Agroekoteknologi 11 (2): 140-149.

Golafrouz H, Safaie N, Khelghatibana F (2020) The reaction of some apple rootstocks to biocontrol of white root rot Rosellinia necatrix by Trichoderma harzianum in greenhouse. Journal of Crop Protection 9 (4): 577-589.

Hardiyanti AR, Yuni SR, Mahanani TA (2014) Efektivitas Waktu Pemberian Trichoderma harzianum dalam Mengatasi Serangan Layu Fusarium pada Tanaman Tomat Varietas Ratna. Lentera Bio: Berkala Ilmiah Biologi 3 (1) : 21-25.

Harjono, Widyastuti SM (2001) Antifungal activity of purified endochitinase produces by biocontrol agent Trichoderma reesei against Ganoderma philippii. Pakistan Journal of Biological Sciences 4 (10):1232-1234. https://doi.org/10.3923/pjbs.2001.1232.1234.

Harman GE (2006) Overvie of Mechanisms and Uses of Trichoderma spp. The American Phytopathological Society 96 (2): 190-194. https://doi.org/10.1094/PHYTO-96-0190.

Jaya A, Lautt BS, Antang EU, Sibot S, Dohong S, Surawijaya P, Dohong S (2020a) Effects of zero burning waste on the quality of liquid fertilizer and vermicompost. International Journal of Agricultural and Biological Engineering 13(4):159-165. https://doi.org/10.25165/j.ijabe.20201304.4814.

Jaya A, Marpaung M, Supriati L, Lautt BS, Antang EU, Sosilawaty (2020b) Effects of Trichoderma sp. and Vermicompost 
for Controlling Sclerotium rolfsii in Chilli pepper crops in Tropical Peat Soil. Agricultural Science Research Journal 10 (5): 105-116.

Joshi R, Singh J, Vig AP (2015) Vermicompost as an effective organic fertilizer and biocontrol agent: effect on growth, yield and quality of plants. Review in Environmental Science Biotechnology 14: 137-159. https://doi.org/10.1007/s11157-014-9347-1.

Komang MN, Kartini L, Atmaja IW (2015) Pengaruh Dosis Pupuk Kascing Terhadap Hasil Tanaman Sawi (Brassica juncea L.), Sifat Kimia dan Biologi Pada Tanah Inceptisol Klungkung. E-Jurnal Agroekoteknologi Tropika 4(3): 170-179.

Lakitan (1996) Fisiologi dan Perkembangan Tanaman. Raja Grafindo Persada. Jakarta.

Manahan S, Idwar, Wardati (2016) Pengaruh Pupuk NPK dan Kascing Terhadap Pertumbuhan Kelapa Sawit (Elaeis guineensis Jacq.) Fase Main Nursery. JOM Faperta 3 (2): 1-10.

Mukherjee P K, Latha J, Hadar R, Horwitz BA (2003) TmkA, a mitogen-activated protein kinase of Trichoderma virens, is involved in biocontrol properties and repression of condition in the dark. Eukaryotic Cell 2(3): 446-455. https://doi.org/10.1128/ EC.2.3.446-455.2003.

Mulat T (2003) Membuat dan Memanfaatkan Kascing Pupuk Organik Berkualitas. Agromedia Pustaka. Jakarta, Pp. 78.

Nofianti N (1999) Kualitas Vermikompos Dari Dua Jenis Cacing (Eisenia foetida dan Phretima sp) Pada Media Campuran Kotoran Sapi Perah. Jakarta. Penebar Swadaya.

Oktarina H, Tjut C, Afriani (2012) Uji Waktu Aplikasi Kascing Untuk Menekan Intensitas Serangan Rhizoctonia solani Kùhn Di Pesemaian Tembakau. Jurnal Agrista16 (2): 107-113.

Oktarina H (2007) Pengaruh Campuran Kascing dengan Media Semai Tembakau (Nicotiana tabacum L.) terhadap Penyakit Rebah Semai (Rhizoctonia solani Kuhn.) di Rumah Kaca. Jurnal Agrista 11 (3): 167-173.

Ordentlich A, Wiesman Z, Gottlieb HE, Cojocaru M, Chet I (1992) Inhibitory furanone produced by the biocontrol agent Trichoderma harzianum. Phytochemistry 31 (2): 485-486. https://doi.org/ 10.1016/0031-9422(92)90021-H.

Pandriyani, Nion YA, Hadi DA (2012) Efektifitas Dosis Trichokompos Ampas Tahu dan Pupuk Kandang Kotoran Ayam untuk Menekan Penyakit Sclerotium rolfsii pada Tanaman Cabai di Tanah Gambut. Jurnal Agripeat 13 (2): 87-95.
Piay SS, Tyasdjaja A, Ermawati Y, Hantoro FRP (2010) Budidaya dan Pascapanen Cabai Merah (Capsicum annuum L.). Badan Penelitian dan Pengembangan Pertanian Balai Pengkajian Teknologi Pertanian Jawa Tengah, Pp. 60.

Rahmadhaini H, Satriawan, Marlina (2017) Pemberian Pupuk Kascing Terhadap Pertumbuhan Dan Hasil Tanaman Kedelai (Glycine max L.). Agrotropika Hayati 4 (3 ) : 224-234.

Rahmawati NUS (2021) Serapan Hara, Pertumbuhan dan Hasil Tanaman Sawi Pakcoy (Brassica Rapa L.) Yang Dibudidayakan Secara Organik dengan Aplikasi Vermikompos. Jurnal Folium 5 (1): 57-68.

Semangun H (1993) Penyakit-Penyakit Tanaman Pangan di Indonesia. Gadjah Mada University Press. Yogyakarta, Pp. 451.

Singh A, Shahid M, Srivastava M, Pandey S, Sharma A, Kumar V (2014) Optimal physical parameters for growth of Trichoderma species at varying $\mathrm{pH}$, temperature and agitation. Virology \& Mycology 3 (1): 1-7. https://doi.org/10.4172/2161-0517.1000127.

Sukamto S (2003) Pengendalian Secara Hayati Penyakit Busuk Buah Kakao dengan Jamur Antagonis Trichoderma harzianum. Prosiding Kongres Nasional XVII dan Seminar Ilmiah PFI, Bandung 6-9 Agustus 2003, Pp 134 - 137.

Sukamto, Dono W (2013) Identifikasi dan Karakterisasi Sclerotium rolfsii Sacc. Penyebab Penyakit Busuk Batang Nilam (Pogostemon cablin Benth). Buletin Penelitian Tanaman Rempah dan Obat 24 (1) : $35-41$.

Sumartini (2012) Penyakit Tular Tanah (Sclerotium rolfsii dan Rhizoctonia solani) Pada Tanaman Kacang-kacangan dan Umbiumbian Serta Cara Pengendaliannya. Jurnal Litbang Pertanian 31 (1) : 27-34

Sunarti T, Made SI, Dewa PS (2015) Uji Efektivitas Bahan Hayati Dari Cacing Tanah (Lumbricus rubellus) Terhadap Perkembangan Populasi Nematoda Puru Akar (Meloidogyne spp.) Pada Tanaman Tomat Varietas Karina (Lycopersicum esculentum Mill.). E-Jurnal Agroekoteknologi Tropika 4 (3): 224-233.

Supriati L, Sri EAR, Syahrudin, Pituati G, Damanik Z, Silitonga L (2007) Pengaruh Pupuk Kandang Sapi dan Trichoderma harzianum Terhadap Perkembangan Sclerotium rolfsii Pada Tanaman Tomat di Tanah Gambut Pedalaman. Jurnal Agripeat 8 (2): 68-75.

Susanna, Tjut C, Arisandi P (2010) Dosis dan Frekuensi Kascing Untuk Pengendalian Penyakit Layu Fusarium Pada Tanaman Tomat. Jurnal Floratek 5: 152 - 163. 
Tindaon H (2008) Pengaruh Jamur Antagonis Trichoderma harzianumdan Pupuk Organik Untuk Mengendalikan Patogen Tular Tanah Sclerotium rolfsii Sacc. Pada Tanaman Kedelai (Glycine max L.) Di Rumah Kaca. USU Repository. Medan.

Tjut C, Rina S, Rahel DS (2011) Efektivitas Dosis dan Waktu Aplikasi Trichoderma virens Terhadap Serangan Sclerotium rolfsii Pada Kedelai. Jurnal Floratek 6: 62 - 73.

Winarso S (2005) Kesuburan Tanah Dasar Kesehatan dan Kualitas Tanah. Penerbit Gava Media. Yogyakarta, Pp. 269.

Wirawan IKJA, Suryana IM, Sukerta IM (2021) Pertumbuhan dan Hasil Tanaman Kangkung Darat (Ipomoea reptans Poir) Akibat
Pemberian Pupuk Kascing. Agrimeta: Jurnal Pertanian Berbasis Keseimbangan Ekosistem 11 (21): 56-60.

Yatoo AM, Ali MN, Baba ZA, Hassan B (2021) Sustainable management of diseases and pests in crops by vermicompost and vermicompost tea. A review. Agronomy for Sustainable Development 41(1): 1-26. https://doi.org/10.1007/s13593-02000657-w.

Zin NA, Badaluddin NA (2020) Biological functions of Trichoderma spp. for agriculture applications. Annals of Agricultural Sciences 65(2):168-178. https://doi.org/10.1016/ j.aoas.2020.09.003. 